\title{
PRINCIPLES OF NEUROCHEMISTRY AND DRUG SCREENING PROCEDURES IN NEUROPSYCHOPHARMACOLOGY
}

\author{
E. Costa \\ Laboratory of Preclinical Pharmacology, National Institute of Mental \\ Health, Saint Elizabeth's Hospital, Washington, D.C. 20032, USA
}

\begin{abstract}
This presentation surveys modern concepts for drug screening as they have emerged from current neurochemical research. Among others, the concept of multiple forms of MAO and phosphodiesterase has revolutionized the approach to drug screening of compounds that change neuronal function through inhibition of these enzymes. Neurochemical progress has opened new vistas and has given indications on how to screen MAO inhibitors for maximum efficacy while avoiding potential side effects. The finding that drugs acting on postsynaptic receptors can now be screened in preparations with receptors made supersensitive by denervation provides another new model, made possible by the discovery that 6-OH-dopamine and 6-hydroxyserotonin can lesion neurons selectively. The use of turnover rate measurements in association with other tests can contribute valuable information on the anatomical site of action of drugs. These tests have a great predictive value if conducted with quantitative criticism of dose-response relations.
\end{abstract}

\section{INTRODUCTION}

Numerous examples can be marshalled to provide evidence that serendipity has played a major role in the discovery of the most important drugs introduced in neuropsychiatry during the last 25 years. However, sporadic exceptions exist. One of them is the successful use of L-dopa as a symptomatic remedy for Parkinson's disease. Undoubtedly, I-dopa would not have been tested without the important discovery made by Ehringer and Hornykiewicz ${ }^{1}$ that a decrease of dopamine concentration in striatum is a symptom of Parkinson's disease. This finding might not have promoted the use of L-dopa as a potential remedy in Parkinsonism ${ }^{2}$ had Blashko ${ }^{3}$ not shown that this amino acid is involved in the biosynthesis of endogenous catecholamines. When L-dopa was first tested in Parkinsonism it was also known that parenteral administration of L-dopa increases the brain concentrations of dopamine in normal animals and in animals treated with reserpine ${ }^{4}$.

A number of drugs presently used in neuropsychiatry were developed 


\section{E. COSTA}

as a result of elaborate programmes of chemical synthesis. Many such programmes evolved from evidence indicating that a given molccular group was responsible for the therapeutic effect of existing remedies. In these attempts such molecular groups were introduced into appropriate chemical structures in order to produce new compounds with a better therapeutic index. Perhaps in these chemical manipulations compounds with unexpected therapeutic properties were obtained, but these properties were not detected because the pharmacological screening of the new molecules was designed to reveal and evaluate the properties of the drug used as a prototype. Thus, our lack of ingenuity in formulating screening procedures has confined many potentially useful drugs to the shelves of drug firms. I am certain that each one of us could mention an appropriate example to support this statement. In fact, a number of drugs have acquired a proper therapeutic indication many years after their synthesis. Often this therapeutic indication is different from that originally intended when these drugs were synthesized. A case in point is $\alpha$-methyl-dopa which was originally synthesized as a potential hypertensive drug, but when tested failed to cause hypertension. Several years later, $\alpha$-methyl-dopa was tested clinically as a hypotensive agent because appropriate screening tests ${ }^{5}$ had shown that this drug could lower the concentrations of norepinephrine in central and peripheral noradrenergic neurons ${ }^{6}$. Apparently, this was a lucky rationalization for $\alpha$-methyl-dopa is still used as a hypotensive agent.

Table 1. Possible sites of interactions between drugs and mechanisms regulating synaptic function

\begin{tabular}{|c|c|c|}
\hline \multirow{2}{*}{ Sites of interaction } & \multicolumn{2}{|l|}{ Drug effects } \\
\hline & Short term & I.ong term \\
\hline Synaptic receptor & Stimulation & $\begin{array}{l}\text { Transynaptic } \\
\text { regulation } \\
\text { of protein } \\
\text { synthesis }\end{array}$ \\
\hline & $\begin{array}{l}\text { Inhibition } \\
\text { Interaction with cyclic nucleotides (second messengers) }\end{array}$ & \\
\hline $\begin{array}{l}\text { Nerve terminal } \\
\text { membrane }\end{array}$ & $\begin{array}{l}\text { Interaction with transmitter retrieval } \\
\text { Dependent on } \\
\text { /neuronal activity }\end{array}$ & $\begin{array}{l}\text { False } \\
\text { transmitter } \\
\text { storage }\end{array}$ \\
\hline & $\begin{array}{l}\text { Interaction with transmitter release } \\
\text { Independent from } \\
\text { neuronal activity }\end{array}$ & \\
\hline Intraneuronal & $\begin{array}{l}\text { Interaction with transmitter storage } \\
\text { Interaction with transmitter synthesis } \\
\text { Interaction with transmitter catabolism }\end{array}$ & $\begin{array}{l}\text { Axonal } \\
\text { transport }\end{array}$ \\
\hline
\end{tabular}

With these considerations in mind, I have decided to talk to you about certain fundamental principles that are emerging from current neurochemical research. With the progress of our understanding of brain biochemistry, these concepts are acquiring increasing value in devising drug screening 
procedures which help us to detect the potential usefulness of new neuropsychiatric drugs.

Table 1 summarizes some regulatory mechanisms of neuronal function which are possible sites for drug action: the receptor, the nerve terminal membrane, and various intraneuronal sites. Each of these sites can participate in short- and long-term regulation of neuronal function: the present report will be mainly concerned with drug action on sites involved in short term regulation of neuronal function. This decision does not imply that long term regulation should not concern pharmacologists: rather it indicates that our knowledge is still too fragmentary to be expressed in suitable models for drug screening.

\section{THE CONCEPT OF POSTSYNAPTIC RECEPTOR IN DRUG DEVELOPMENT}

The discovery that $3^{\prime}, 5^{\prime}$-cyclic AMP catalyzes the enzymatic phosphorylation of proteins by kinases ${ }^{7}$ and the realization that the function of membrane-bound adenylate cyclase can be regulated by catecholamines ${ }^{8}$, including norepinephrine $(\mathrm{NE})^{9}$ and dopamine $(\mathrm{DM})^{10}$, have prompted a drastic revision in the conceptualization of the biochemistry of postsynaptic receptors. Catecholamines and, perhaps, other putative transmitters, activate the membrane-bound adenylate (or guanylate) cyclase increasing the formation of cyclic nucleotides from ATP and GTP. We do not understand how these nucleotides can elude inactivation by phosphodiesterase, a soluble enzyme present in cytoplasm, to convey intracellularly the message brought to the cell surface by the transmitter. However, the $3^{\prime}, 5^{\prime}$-cyclic AMP (termed second messenger) and the intracellular mechanisms that make its action possible, should now be considered as an important site for the action of drugs that mimic the effects of certain transmitters. Since there are different molecular forms of phosphodiesterases ${ }^{11}$, which may be cell specific ${ }^{12}$ and possess different sensitivity toward drug inhibition, the ubiquitous adenylate cyclase system may be manipulated pharmacologically with some degree of selectivity. Probably the postsynaptic receptor uses the adenylate cyclase as a transducer to transform the synaptic event into a message for the mechanisms that control protein synthesis in the postsynaptic cell.

\section{Receptor stimulants}

\section{(i) Direct stimulants}

The studies of cholinergic and noradrenergic peripheral neurons have pioneered the present understanding of synaptology by proving that neurons control the cells they innervate by secreting appropriate chemical mediators at synapses. The secretion of these transmitters enables neurons either to initiate a variety of responses in the postsynaptic cell (contraction of striated muscles, secretion of glands, etc.) or to modulate the frequency of spontaneous rhythmical activities in cells endowed with such a property.

More than thirty years ago, as a corollary to these studies, Dale formulated a basic axiom concerning the chemical nature of synaptic transmitters. This axiom, which is still widely accepted on its intrinsic merit, postulates that 


\section{E. COSTA}

each neuron synthesizes, stores, and secretes one and only one type of transmitter. This concept coupled with the uniformity of responses elicited by a given transmitter in a given peripheral tissue (contraction of striate muscles, secretion of salivary glands, etc.) has contributed to the expectation that, in the brain, drugs which mimic a given transmitter elicit a defined functional and behavioural response. Of course, when such drugs are administered systemically, they elicit complex responses due to stimulation of the numerous specific receptors located in neuronal systems involved in the control of diversified neuronal mechanisms. Such unexpected complexities of drug effects are usually referred to as side effects of the drug. This is a misnomer. These side effects are not collateral and unexpected effects of the drug, but they reflect the stimulation of identical receptors involved in other brain functions. As an example, we may take chlorpromazine and other neuroleptics chemically related to chlorpromazine. It is presently believed that these drugs elicit their action because they occupy dopaminergic receptors where they prevent the action of dopamine ${ }^{13}$. It is, therefore, not surprising that after prolonged administration, the neuroleptic action is contaminated by extrapyramidal disturbances because dopaminergic receptors identical to those necessary for the neuroleptic action are involved in the regulation of extrapyramidal function. Similar considerations apply to the emesis occurring during the administration of L-dopa to Parkinsonian patients: this reflects the involvement of dopamine receptors in the function of the myelencephalic trigger zone, a site of convergence for neuronal activity involved in the control of vomiting.

Table 2. Structures innervated by dopaminergic, serotonergic, and noradrenergic neurons in rat brain

\begin{tabular}{|c|c|c|}
\hline $\begin{array}{l}\text { Cell bodies } \\
\text { localization }\end{array}$ & $\begin{array}{l}\text { Transmitter } \\
\text { stored }\end{array}$ & $\begin{array}{c}\text { Brain structure } \\
\text { innervated }\end{array}$ \\
\hline $\begin{array}{l}\text { Substantia } \\
\text { nigra }\end{array}$ & Dopamine & $\begin{array}{l}\text { Limbic forebrain } \\
\text { Neo striatum }\end{array}$ \\
\hline $\begin{array}{l}\text { Locus } \\
\text { coeruleus }\end{array}$ & Norepinephrine & $\begin{array}{l}\text { Cerebellum } \\
\text { Limbic forebrain } \\
\text { Thalamus } \\
\text { Hypothalamus }\end{array}$ \\
\hline $\begin{array}{l}\text { Raphe } \\
\text { medianus }\end{array}$ & Serotonin & $\begin{array}{l}\text { Paleostriatum } \\
\text { Neostriatum } \\
\text { Limbic forebrain } \\
\text { Cerebellum } \\
\text { Thalamus } \\
\text { Hypothalamus } \\
\text { Spinal cord }\end{array}$ \\
\hline
\end{tabular}

To recapitulate this point, let us consider the data reported in Table 2 which illustrates the projection of noradrenergic, dopaminergic, and serotonergic neurons to various brain structures. This Table includes only three putative transmitters but there is reason to believe that other neuronal systems may display an equally diffuse innervation. This suggests that many 
different brain structures are regulated by the same transmitter. Electrophysiological studies on neuronal responses to the application of various transmitters in the vicinity of neuronal cell bodies show that the application of a given putative transmitter elicits very similar responses in various neuronal populations ${ }^{14}$ of brain. Therefore, one can summarize, that the effects on the excitability of the neuronal membrane are not different.

In conclusion, a selectivity of neurological and behavioural responses is at best the exception in the pharmacological profile of drugs which directly activate the postsynaptic receptors of a given neurotransmitter. Perhaps when pathological conditions resembling surgical denervation change receptor function, its susceptibility to the action of drugs that mimic the transmitter can be enhanced (denervation supersensitivity). This enhancement results in a certain degree of selectivity of the drug response in the

Table 3. Selective depletion of spinal cord 5-HT by intracisternal injection of 6-hydroxyserotonin $(6-\mathrm{HS})^{*}$

\begin{tabular}{|c|c|c|c|c|c|c|}
\hline \multirow{2}{*}{ Brain structure } & \multicolumn{2}{|c|}{$\begin{array}{c}\text { Dopamine } \\
\text { nmole } \mathrm{g}^{-1} / \pm \mathrm{SE}\end{array}$} & \multicolumn{2}{|c|}{$\begin{array}{c}\text { Serotonin } \\
\text { nmole } \mathrm{g}^{-1} / \pm \mathrm{SE}\end{array}$} & \multicolumn{2}{|c|}{$\begin{array}{l}\text { Norepinephrinc } \\
\text { nmole } \mathrm{g}^{-1} / \pm \mathrm{SE}\end{array}$} \\
\hline & Saline & 6-HS & Saline & 6-HS & Saline & 6-HS \\
\hline Spinal cord & - & - & $4.3 \pm 0.04$ & $1.8 \pm 0.12^{*}$ & $1.9 \pm 0.12$ & $2.2 \pm 0.12$ \\
\hline Medulla pons & $\ldots$. & - & $4.9+0.57$ & $5.7+0.21$ & $3.5+0.23$ & $3.5+0.14$ \\
\hline Hypothalamus & - & - & $9.5 \pm 1.5$ & $7.7 \pm 0.59$ & $11 \pm 0.76$ & $10 \pm 1.5$ \\
\hline Cerebellum & - & - & $1.8 \pm 0.14$ & $1.6 \pm 0.15$ & $1.6 \pm 0.19$ & $1.5 \pm 0.08$ \\
\hline Telencephalon & $3.8 \pm 2.6$ & $4.2 \pm 2.8$ & $1.9 \pm 0.12$ & $1.6 \pm 0.22$ & $1.5 \pm 0.1$ & $1.6 \pm 0.11$ \\
\hline
\end{tabular}

* $6 \mathrm{HS}(0.39 \mu \mathrm{mole} / \mathrm{rat})$ was injected 14 days before the assay $\mathrm{P}<0.01$

denervated receptors. When the location of the pathological condition affecting receptor function is known and if the nerves afferent to this brain area are accessible, a denervated preparation may be an appropriate model system to screen the efficacy of receptor stimulants. An index of the selectivity of this drug response can be obtained by comparing responses elicited in intact and in denervated preparation. An example of this type of screening is the one currently employed for drugs to be used in Parkinson's disease. In rats the monolateral injection of 6-hydroxydopamine ${ }^{15}$ in the substantia nigra selectively destroys the cell body of the dopaminergic neurons of the nigro-striatal pathway (Table 2). These rats either exhibit circling toward the lesioned side or remain immobile. The injection of drugs that mimic the effects of dopamine on striatal receptors causes intense circling away from the lesioned side. With this preparation, one can have a realistic appreciation of the therapeutic index of the drug in conditions of receptor supersensitivity. Similar screening models can be devised for noradrenergic receptors which can be denervated by injections of 6-hydroxydopamine in appropriate brain regions and for serotonergic receptors which can be denervated by injections of 6-hydroxyserotonin (6-HS) ${ }^{16}$. This drug injected intracisternally destroys serotonergic nerve terminals of spinal cord selectively (Table 3). 


\section{E. COSTA}

Since serotonergic function is involved in spinal reflexes, it may turn out that pretreatment with 6-HS may be a suitable model to test drugs that directly stimulate serotonergic receptors.

\section{(ii) Indirect stimulants.}

The term 'indirect stimulation of postsynaptic receptors' describes the effect of drugs which increase the amount of transmitter reaching postsynaptic receptors. These drugs may interfere with various mechanisms regulating the release from nerve endings of the transmitter. These mechanisms are located either in the membrane of the nerve terminal or extraneuronally in the vicinity of the postsynaptic receptors. Here we shall consider only those mechanisms which are extraneuronally located and are enzymatic in nature. These mechanisms have a particular importance for the cholinergic mechanism and influence the noradrenergic function to a much smaller extent. The two enzymes involved are termed acetylcholinesterase and catecholamine- $O$-methyltransferase. Several inhibitors of cholinesterases have been developed. Due to the diffuse distribution of brain cholinergic receptors, the use of these drugs is plagued by a great number of collateral effects. A certain degree of specificity can be conferred on this inhibitory effect by altering the physicochemical properties of the drug and these molecules can thus be excluded from the brain. However, when they are used to modify abnormalities of cholinergic receptor functions, the anticholinesterases exhibit a limited specificity.

In conclusion, the experience acquired on the indirect stimulation of synaptic receptors by inhibitors of the enzymes that inactivate the transmitter does not predict encouraging prospects for future drug developments.

\section{Receptor inhibitors}

Inhibition of postsynaptic receptors may lack an appropriate selectivity for reasons similar to those mentioned earlier in this report with regard to stimulation of postsynaptic receptors. Since the transmitter concentrations at receptors is a factor that controls the affinity constant of receptor blockers that act competitively, rates of transmitter release should be considered as a variable in the efficacy of these drugs. To assess this variable, the potency of these inhibitors should be tested in experimental conditions where the spontaneous rates of transmitter release from pertinent nerve terminals are different. During adaptation to cold exposure, the activity of certain central and peripheral catecholaminergic neurons is increased. This increase can be estimated in vivo by measuring the turnover rate of the transmitter involved. Using this approach, we have estimated NE and DM turnover rate in various tissues or brain regions of rats kept at two different environmental temperatures. The data of Table 4 show that the turnover rate of heart and cerebellar NE is increased by cold exposure. From this finding one can infer that the central and peripheral catecholaminergic neurons do not respond to stressful situations with a diffuse and generalized increase of activity. Cold exposure may therefore be a suitable screening device to estimate the efficacy of postsynaptic receptor blockers in relation to various rates of neuronal activity. 
Table 4. Turnover rate of dopamine (DM) and norepinephrine (NE) in various tissues of rats kept at $20^{\circ} \mathrm{C}$ and $4^{\circ} \mathrm{C}$

\begin{tabular}{|c|c|c|c|c|c|c|}
\hline \multirow{2}{*}{ Tissue } & \multirow{2}{*}{ Catecholamine } & \multicolumn{3}{|c|}{ nmole $\mathrm{g}^{-1} / \pm \mathrm{SFM}$} & \multicolumn{2}{|c|}{ nmole g ${ }^{1} \mathrm{~h}^{1}{ }^{1}$} \\
\hline & & & $20^{\circ} \mathrm{C}$ & $4^{\circ} \mathrm{C}$ & $20^{\circ} \mathrm{C}$ & $4^{\circ} \mathrm{C}$ \\
\hline Heart & $\mathrm{NE}$ & & \pm 0.43 & $5.3 \pm 0.48$ & 0.78 & $2.2^{*}$ \\
\hline Salivary gland & $\mathrm{NE}$ & 7.4 & 0.58 & $7.8 \pm 0.37$ & 0.81 & 0.86 \\
\hline Stomach & NE & & \pm 0.27 & $3.2+0.45$ & 0.25 & 0.26 \\
\hline Cerebellum & NE: & & $4 \pm 0.093$ & $1.2 \pm 0.11$ & 0.32 & $0.96^{*}$ \\
\hline Hypothalamus & $\mathrm{NE}$ & 8.5 & \pm 0.82 & $8.7 \pm 0.57$ & 2.6 & 2.5 \\
\hline Striatum & DM & 82 & \pm 6.3 & $94 \pm 5.4$ & 28 & 33 \\
\hline
\end{tabular}

* $k$ significantly different from that of rats kept at $20^{\circ} \mathrm{C}$. Rats were kept at the indicated temperature for 14 hours beforc measuring turnover rate of NE by an isotopic method (pulse injection of $3,5 \cdot{ }^{3} \mathrm{H}$ tyrosine).

In vivo blockade of postsynaptic receptors is associated with an increased turnover rate of the transmitter stored in the nerve terminals facing the postsynaptic receptor that is blocked. This increasc has been explained by several mechanisms: (a) collateral neuronal loops emanating from the cell inhibited by the blocker; (b) blockade of presynaptic receptors which are important to regulate transmitter release; (c) interference with reuptake mechanisms.

\section{Postsynaptic receptors and second messenger as a site for drug action}

Various schemes have been presented to depict how the message brought about by the action of the transmitter on receptors in the postsynaptic membrane is transferred to the pertinent intracellular compartments for further elaboration and transaction. Experiments performed with pineal gland $^{9}$, cervical sympathetic ganglia ${ }^{10}$, and adrenal medulla ${ }^{16}$ have clearly indicated that the stimulation of postsynaptic receptors may be linked with a change in the membrane-bound adenyl cyclase activity of postsynaptic cells. As first suggested by Sutherland and co-workers ${ }^{17}$, the adenyl cyclase associated with postsynaptic receptors may be viewed as formed by a regulatory and catalytic unit; the transmitter would bind to the regulatory unit and by this binding alter the basic rate of intracellular formation of $3^{\prime}, 5^{\prime}$-cyclic adenosine monophosphate (cAMP). This nucleotide is believed to activate various enzymes intracellularly; since it mediates the effects of hormones and transmitter, it has been termed 'second messenger'. As an example of this interaction, we report in Table 5 the effect of carbamylcholine injected into monolaterally splanchnicotomized rats on the cAMP concentration of normal and denervated adrenal medulla. These data show that this parasympathomimetic increases the concentration of cAMP in intact and splanchnicotomized medulla. Note the rapid rate of accumulation of cAMP at the time approach peak effect; this rate assures that an amount of cAMP equal to the steady state concentration of the nucleotide accumulates in the tissue in about one minute. Carbamylcholine, in vitro, does not reduce the activity of phosphodiesterase, the enzyme that catabolizes cAMP. Therefore, one must assume that under the stimulatory action of carbamyl- 


\section{E. COSTA}

choline, the turnover time of cAMP in adrenal medulla, it is even greater than that mentioned above because the nucleotide is continually metabolized while it accumulates in the medulla as a result of carbamylcholine action. Although the catabolic rate of medullary cAMP cannot be estimated precisely, it seems conceivable that it should be at least equal to the rate of cAMP accumulation elicited by aminophylline, a drug that inhibits phosphodiesterase. To estimate this rate, we have measured the cAMP accumulation in intact and splanchnicotomized adrenal medulla of rats receiving $200 \mu$ moles $\mathrm{kg}^{-1}$ i.p. of aminophylline. These data are reported in Table 5 and show that the rate of accumulation is greater in intact than in splanchnicotomized adrenal medulla. Since we have shown that aminophylline inhibits equally well the phosphodiesterase of normal and denervated adrenal medulla, we conclude that the afferent neurons to adrenal medulla regulate cAMP turnover rate by acting on adenyl cyclase.

Table 5. c-AMP concentrations in intact and splanchnicotomized medulla of rats receiving carbamylcholine $\left(8.2 \mu\right.$ mole $\mathrm{kg}^{-1}$ i.p. $)$ or aminophylline $\left(200 \mu\right.$ mole kg-1 ${ }^{-1}$ i.p. $)$

\begin{tabular}{|c|c|c|c|c|}
\hline \multirow{3}{*}{$\begin{array}{l}\text { Minutes after } \\
\text { injection }\end{array}$} & \multicolumn{4}{|c|}{ c-AMP p mole $\mathrm{mg}^{-1}$ protein $($ Mean $\pm \mathrm{SE})$} \\
\hline & \multicolumn{2}{|c|}{ After carbamylcholine } & \multicolumn{2}{|c|}{ After aminophylline } \\
\hline & Normal & Splanchnx & Normal & Splanchnx \\
\hline 0 & $33+3.0$ & $32+2.3$ & $42+9$ & $38+4.6$ \\
\hline 3 & $30 \pm 7.0$ & $37 \pm 8.0$ & $88 \pm 25$ & $55 \pm 12$ \\
\hline 6 & $53 \pm 2.6$ & $49 \pm 5.6$ & $190 \pm 57$ & $75 \pm 20$ \\
\hline 12 & $200 \pm 77$ & $200 \pm 67$ & $420 \pm 80$ & $120 \pm 75$ \\
\hline 24 & $450 \pm 7.0$ & $380 \pm 54$ & $380 \pm 95$ & $200 \pm 60$ \\
\hline 48 & $110 \pm 12$ & $100 \pm 19$ & $500 \pm 60$ & $220 \pm 40$ \\
\hline
\end{tabular}

Splanchnx was performed five days before the experiments. Each value is the mean of at least four experiments. The c-AMP was assayed by the luciferin-luciferase method

If, as will be shown later, cAMP plays a regulatory role in the elaboration of synaptic activity impinging upon the membrane of chromaffine cells, then one might change the response of the postsynaptic cells by injecting drugs that can modulate cAMP metabolism. An obvious site for this regulation is the phosphodiesterase. Uzunov and Weiss ${ }^{11}$ reported that the soluble supernatant fraction of rat cerebellar homogenates contains various enzyme proteins with phosphodiesterase activity which can be separated by electrophoresis on a preparative polacrylamide gel column. Analyzing successive fractions of the column eluate for phosphodiesterase activity they found five distinct peaks of enzymatic activity designated $\mathrm{I}$ to $\mathrm{V}$ according to the order in which they emerged from the column. They also detected a discrete fraction containing a potent phosphodiesterase activator. This protein increases the activity of peak II about fourfold and that of peak V about two-fold, whereas the activities of peaks I, III, and IV were unaffected by the activator. $\mathrm{Ca}^{2+}$ increased the activity of peak II only. The five peaks 
DRUG SCREENING IN NEUROPSYCHOPHARMACOLOGY

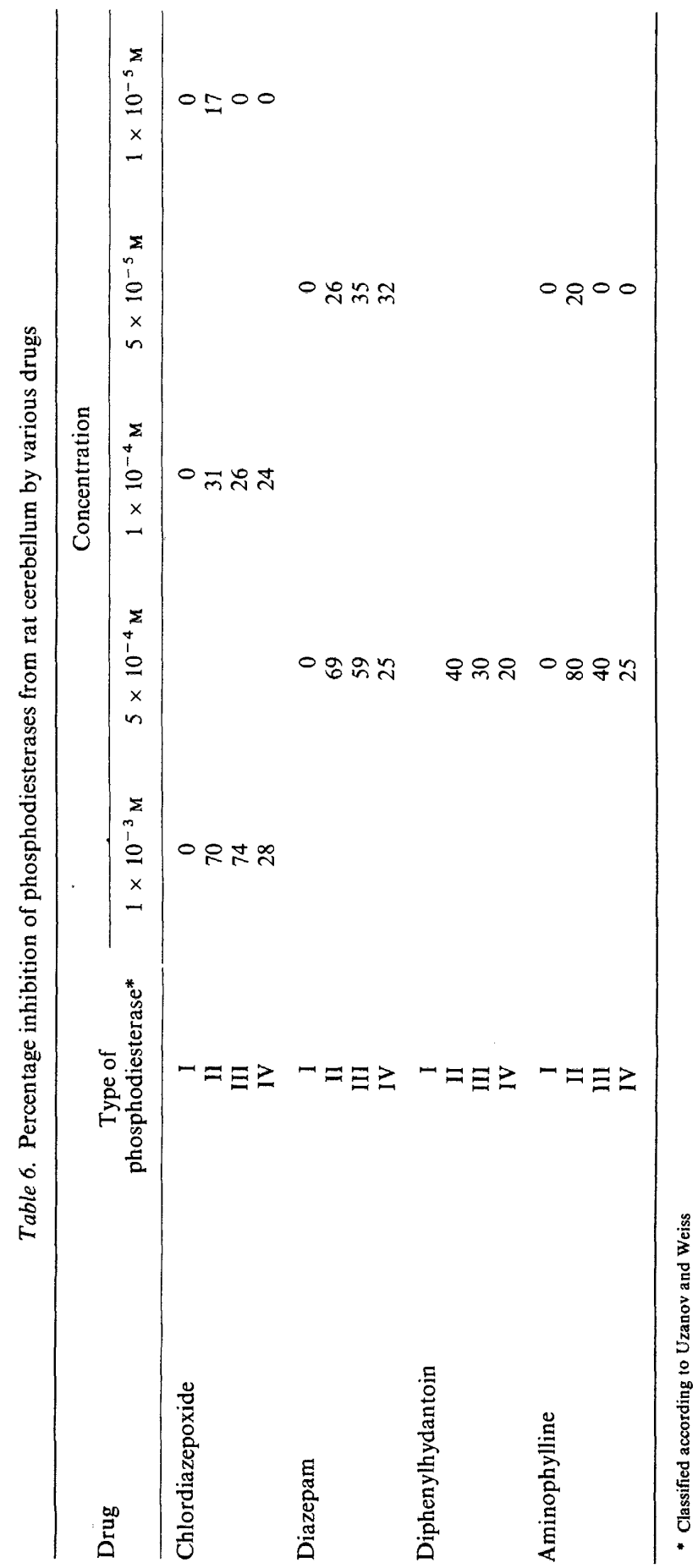




\section{E. COSTA}

of phosphodiesterase also had markedly different stabilities, peaks III and V being the least stable ( $t_{\frac{1}{2}}$ of 1 day when stored at $4{ }^{\circ} \mathrm{C}$ ).

In other studies, Uzunov and collaborators ${ }^{12}$ established that in cell cultures on neuroblastoma, only peak III was present. Thus, the enzyme associated with peak 111 is of particular interest in screening neuropsychiatric drugs because it appears to reside in neurons. Since the adenylate cyclase system is ubiquitous and of physiological importance in various cells, the possibility of interfering selectively with neuronal phosphodiesterase appears to be an essential prerequisite for drug action in central nervous system. Drs. Strada and Suria have initiated such an exploration and their preliminary results are reported in Table 6.

The data reported in Table 6 show that diazepam is slightly more effective than aminophylline in inhibiting the phosphodiesterase present in neurons (peak III). Moreover, if the activity of diazepam is compared with that of chlordiazepoxide, the former appears to be five-fold more active than the latter. Not only are these benzodiazepines structurally related to diphenylhydantoin, but they share its anticonvulsant action. The data reported in Table 6 show that diphenylhydantoin is weaker than either benzodiazepine as a phosphodiesterase inhibitor. This finding may be relevant to explain the anticonvulsant activity of diphenylhydantoin and benzodiazepines because an action on the Purkinje cells of ccrebellum appears to be important for their anticonvulsant effect ${ }^{18,19}$. It may be pertinent to note that NE injected microiontophoretically hyperpolarizes the Purkinje cells and this action appears to be mediated through $\mathrm{CAMP}^{20}$. It is also of interest that the phosphodiesterase inhibitory potencies of these three compounds rank in a sequence similar to their anticonvulsant activity.

\section{Trans-synaptically controlled long-term regulation of neuronal function}

Two main lines of evidence have contributed to our present understanding of the long-term regulation of tyrosine hydroxylase activity in the adrenal medulla. One was provided by Axelrod ${ }^{21}$ by showing that tyrosine hydroxylase activity is regulated trans-synaptically, the other by Kvetnansky and collaborators $^{22}$ by showing that an injection of dibutyryl cyclic AMP restores the activity of tyrosine hydroxylase in hypophysectomized rats. Since afferent cholinergic nerves to the adrenal regulate medullary adenyl cyclase, we have investigated whether the prolonged increase of cyclic AMP in adrenal medulla elicited by aminophylline (Table 5), carbamylcholine (Table 5), and reserpine (Table 7) would be associated with a delayed increase of the tyrosine hydroxylase activity of adrenal medulla. To establish such a relationship, we have investigated whether drugs which promptly increase the concentration of medullary cAMP can after several hours increase the tyrosine hydroxylase activity of adrenal medulla. The results of these experiments are reported in Table 7.

These data show that the peak increase in cAMP concentrations is attained in about 12 minutes but the increase of tyrosine hydroxylase activity occurs 10 to 14 hours after the drug injection. The data reported in Table 7 show that after injecting the various tyrosine hydroxylase inducers, accumulation of cAMP at its peak does not rank in parallel with the increase of tyrosine hydroxylase activity. However, the rate of cyclic AMP accumulation appears 
related to the increase of tyrosine hydroxylase activity. We are presently investigating the sequence of biochemical events occurring in the time interval elapsing between accumulation of cAMP and the increase of tyrosine hydroxylase activity; we are now studying whether protein kinase activation and phosphorylation of acidic nuclear proteins and histones are among the events occurring in this time interval. In neurons, trans-synaptically mediated enzyme induction may be a physiological mechanism; accordingly, alteration of the trans-synaptic control of enzyme induction may cause neuronal pathology.

Table 7. Delayed increase of tyrosine hydroxylase activity and immediatc accumulation of c-AMP in intact and denervated adrenal medulla of rats receiving various tyrosine hydroxylase inducers

\begin{tabular}{|c|c|c|c|c|}
\hline \multirow[b]{2}{*}{ Inducing drug } & \multirow[b]{2}{*}{$\begin{array}{l}\text { Denerva- } \\
\text { tion }\end{array}$} & \multicolumn{2}{|c|}{ Immediate changes in c-AMP' } & \multirow[b]{2}{*}{$\begin{array}{c}\text { Delayed changes in } \\
\text { tyrosine hydroxylase } \\
\text { activity as } \% \text { of } \\
\text { normal }\end{array}$} \\
\hline & & $\begin{array}{l}\text { Extent of } \\
\text { accumula- } \\
\text { tion as } \% \text { of } \\
\text { normals }\end{array}$ & $\begin{array}{l}\text { Accumulation } \\
\text { rate } \\
\text { (pmole } \mathrm{mg}^{-1} \text { pro- } \\
\text { tein } \min ^{-1} \text { ) }\end{array}$ & \\
\hline Reserpine & No & 400 & 11 & $180^{*}$ \\
\hline (16 $\mu$ mole $\mathrm{kg}^{-1}$ i.p.) & Yes & 150 & 3 & 107 \\
\hline \multirow[t]{2}{*}{ Carbamylcholine } & No & 1500 & 25 & $180^{*}$ \\
\hline & Yes & 1100 & 25 & $150^{*}$ \\
\hline Aminophylline & No & 1200 & 40 & $190^{*}$ \\
\hline$\left(200 \mu\right.$ mole $\mathrm{kg}^{-1}$ i.p. $)$ & Yes & 500 & 6 & 130 \\
\hline
\end{tabular}

$* \mathrm{P}<0.05$

The maximal accumulation of c-AMP is attained in about 12 minutes after drug injection. The accumulation rate of c-AMP is calculated from c-AMP concentrations measured between 6 and 12 minutes after the injection.

\section{Methods to estimate drug effects on nerve terminal function}

In Table $1 \mathrm{I}$ have listed several mechanisms located either on the nerve terminal membrane or intraneuronally, which are involved in the short- and long-term regulation of neuronal function. Some of these mechanisms can be easily tested in vitro in connection with drug screening. These include: (i) synthesis, (ii) catabolism, and (iii) uptake of transmitters.

\section{(i) Synthesis}

Transmitter biosynthesis is sometimes regulated through a feedback control by product inhibition of the rate-limiting enzyme for the transmitter biosynthesis. Actually, of the three best known putative transmitters, only the biosynthesis of catecholamines is regulated through a product inhibition of tyrosine hydroxylase activity ${ }^{25}$. The details of such a negative feedback are not thoroughly understood. It is known that catecholamines inhibit tyrosine hydroxylase by interfering with the pteridin cofactor ${ }^{26}$, essential 


\section{E. COSTA}

for the function of this enzyme. Among the endogenous catechols, the highest affinity for this regulatory mechanism is displayed by DM. Since this NE precursor is free in the cytosol of sympathetic nerves where tyrosine hydroxylase is also located, DM may play a physiological role in the in vivo control of tyrosine hydroxylase ${ }^{27}$. If an excessive production of tyrosine hydroxylase were to be a recognized pathological cause of noradrenergic nerve disfunction, one may attempt to correct this defect by administering drugs that mimic the effect of DM or NE in the regulation of tyrosine hydroxylase activity, but not in their physiological action or in their binding properties to storage sites. Another approach to reduce excessive synthesis is to find inhibitors of pteridin reductase, the enzyme that maintains optimal concentrations of reduced pteridin cofactor ${ }^{28}$.

The regulation for serotonin and acetylcholine biosynthesis seems to depend on the availability of substrate for the hydroxylating and acetylating enzyme, respectively. Thus within limits, serotonin synthesis depends on the concentrations of tryptophan available while acetylcholine synthesis is regulated by the availability of choline at the site of synthesis. However, the mechanisms involved are only apparently similar; in the case of acetylcholine, due to the excess of choline acetyltransferase, short-term regulation depends on the retrieval of choline by the nerve terminals ${ }^{29}$. Since this choline is formed from the recently-released acetylcholine, the rate of choline uptake regulates acetylcholine synthesis and relates to that of neuronal activity. Also, in the case of brain serotonin biosynthesis, the enzymes involved are not saturated by their respective substrates. Availability of substrates may also have a regulatory order. The regulation of the tryptophan availability at the sites of synthesis depends on the concentrations of freelydiffusable plasmatic tryptophan. Since free tryptophan is in equilibrium with tryptophan ionically bound to plasma protein, it follows that any molecule that competes with tryptophan for its binding sites in plasma might alter serotonin synthesis in brain. It remains to be ascertained whether the increase of 5-HT synthesis elicited by excesses of tryptophan availability has a functional significance.

The three types of regulation of transmitter biosynthesis described above are currently being studied in various laboratories; the outcome of such experiments may be of importance for future development of new drug screening procedures.

\section{(ii) Metabolism}

The existence of multiple forms of monoamine oxidase (MAO) has received strong support by a number of recent reports ${ }^{30-32}$. Johnston ${ }^{31}$ has reported that clorgyline allows for the distinction of two forms of MAO in rat brain homogenates, an enzyme form termed Type A which is inhibited by low concentrations of clorgyline and an enzyme form designated as Type B which is relatively insensitive to these concentrations of clorgyline. The Type A enzyme is more effective than Type B enzyme in metabolizing serotonin while both enzymes are equally effective in metabolizing tyramine. Independent reports by Jarrot ${ }^{33}$ and by Neff and Goridis ${ }^{32}$ have shown that sympathetic nerves contain predominantly Type A MAO and that Type A 
enzyme is very effective in metabolizing not only serotonin, but also norepinephrine and normetanephrine. Probably Type A enzyme is not a single entity; the ratio of tyramine to serotonin metabolized by Type A enzyme varies from tissue to tissue. Type B enzyme preferentially deaminates benzylamine. Tryptamine and dopamine, like tyramine, are metabolized equally well by both types of enzyme. This specificity of various forms of MAO toward certain substrates and their different sensitivity toward certain inhibitors opens new avenues for drug development in the field of MAO.

It is well known that the ingestion of foods containing high concentrations of biogenic amines by individuals receiving MAO inhibitors evokes episodes which resemble the clinical picture of pheochromocytoma (transient hypertension, headache, palpitation, nausea, vomiting, etc.). These symptoms are due to high blood levels of biogenic amines which are not detoxified by the

Table 8. In vitro properties of some MAO inhibitors*

\begin{tabular}{lccccc}
\hline \multicolumn{1}{c}{ Drug } & \multicolumn{3}{c}{ MAO inhibition $\left(K_{1}\right)$} & & $\begin{array}{c}\text { Vas deferens } \\
\text { (Tyramine } \\
\text { potentiation) }\end{array}$ \\
\cline { 2 - 5 } & $\begin{array}{c}\text { Phenethylamine } \\
\text { or } \\
\text { benzylamine }\end{array}$ & Tyramine & Serotonin & & \\
\hline Lilly 51641 or clorgyline & 600 & $(\mathrm{P})$ & 300 & 1 & $(?)$ \\
Tranylcypromine & $0.067(\mathrm{P})$ & 0.033 & 1 & + \\
Pargyline & $0.05(\mathrm{P})$ & 0.05 & 1 & + \\
Deprenyl & 0.01 & $(\mathrm{~B})$ & $?$ & 1 & Antagonism \\
\hline
\end{tabular}

* Data from: J. Knoll and K. Magyar, Adr. Biochem. Psychopharm. 5, 393 (1972): R. W. Fuller, Ibid, 5. 339 (1972).
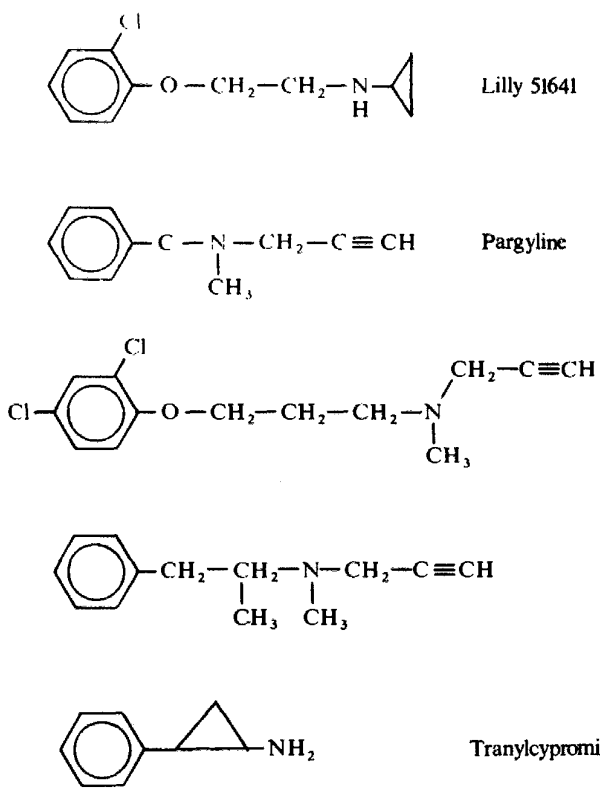
liver enzyme. With the discovery of selective inhibitors of Type A enzymes, it appears that one might influence metabolism of serotonin and norepinephrine in monoaminergic nerves which contain Type A enzyme without altering the destruction by Type B enzyme of liver of the amines absorbed from the intestine. The data reported in Table 8 show that the concentrations of clorgyline or Lilly 51641 required to block the metabolism of phenethylamine or tyramine are 600 - and 300 -fold greater than those required to inhibit 5-HT metabolism. In contrast, MAO inhibitors used clinically (pargyline and tranylcypromine) inhibit the metabolism of phenethylamine or tyramine better than that of 5-HT. Although the difference in affinity for various substrates displayed by Lilly 51641 may not yet be sufficient to obtain a satisfactory therapeutic index, it is possible that compounds with a satisfactory therapeutic index may be developed following such an approach.

Finally, I would like to draw attention to deprenyl, a MAO inhibitor developed by Knoll and Magyar ${ }^{34}$ which fails to potentiate and may antagonize the biological effects of tyramine. They also obtained a very flat dose response curve for the inhibition of tyramine metabolism by this drug and a very prominent inhibitory activity toward benzylaminc. This peculiar relationship suggests that the antienzymatic properties of deprenyl against various substrates should be studied more thoroughly because in the light of present developments, its weak inhibitory effect against tyramine should be considered an advantageous property.

\section{(iii) Uptake mechanisms}

Nerve terminals in the brain possess specialized uptake mechanisms for a variety of putative neurotransmitters, such as dopamine, norepinephrine, serotonin, choline, $\gamma$-aminobutyric acid, glutamic acid and glycine ${ }^{35,36}$. Kinetic studies have elucidated optimal conditions for nerve endings to accumulate selectively their specific transmitter. By separating with density gradient centrifugation the synaptosomes (pinched-off nerve endings present in brain homogenates), populations of brain neurons relatively uniform with regard to the transmitter content can be separated and their biochemical properties studied. With regard to drug screening, it is important to consider that inhibition of monoamine uptake is a possible mechanism of action for various neuropharmacological agents. If a compound preferentially inhibits uptake of a transmitter, one usually infers that when this drug is injected into the animal, it will increase the time course of the transmitter-receptor interaction and will therefore prolong the duration of the receptor stimulation by the natural transmitter. Conceptually, this inference is acceptable, but it may not be practically verified because it implicitly assumes that a drug injected in vivo causes only one action. To verify whether blockade of uptake operates in vivo, one can integrate the results of in vitro measurements of uptake with turnover rate estimation of the transmitter in vivo.

\section{Storage and release of transmitter as sites for drug action}

Acetylcholine $^{37}$, catecholamine ${ }^{38}$, and serotonin ${ }^{39}$ are stored in nerve endings bound to synaptic vesicles. Nerve impulses release the transmitter by partial exocytosis ${ }^{40}$, whereby only part of the vesicle content is ejected in the synaptic cleft. However, in this process not only the transmitter but 
also enzyme proteins and other proteins contained in the synaptic vesicle reach the extracellular fluid ${ }^{40}$. Partial exocytosis brings the inside of each vesicle into contact with the extracellular fluid several times during its life cycle. Since during each exposure a proportion of the synaptic vesicles content is lost and since protein synthesis in nerve terminals is minimal and localized to the mitochondria, the participation of a given synaptic vesicle to successive partial exocytoses causes its reduction in size and its increase in electron density. Thus reduction in size expresses aging. This morphological counterpart of aging might explain the polymorphism exhibited by synaptic vesicles stored in a nerve terminal; the vesicles of small size and with dense core being the oldest members of the population of synaptic vesicles of a nerve terminal. Some authors have proposed that the smallest vesicles do not participate to exocytosis but still exchange their material with surrounding younger vesicles ${ }^{40}$.

The various mechanisms involved in the storage process are not entirely understood; it is known that monoaminergic synaptic vesicles contain ATP and transmitter in a fixed ratio ${ }^{41}$. The storage process is sensitive to drug action, reserpine being the prototype of drugs that inhibit amine storage irreversibly ${ }^{42}$. In fact, in animals receiving reserpine, storage is back to normal only after the population of synaptic vesicles is completely renovated $^{43}$. Although it is conceivable that reserpine binds covalently to some constituents of the synaptic vesicle, the molecular nature of the reserpine receptor is not known. Moreover, the reserpine receptor is not a generalized receptor present in all synaptic vesicles. Presumably, the vesicles that store GABA and acetylcholine are not affected by reserpine.

In practice there are simple neurochemical tests that characterize a reserpine-like action. These are: measurement of tissue monoamine concentrations; measurements of the brain concentrations of NE and 5-HT acidic metabolites; estimations of monoamines uptake with and without MAO inhibitors; estimation of the uptake of an $\alpha$-methyl-monoamine; assay of RNA concentrations in the cell body of monoaminergic neurons ${ }^{44}$; and measurement of the activity of enzymes involved in monoamine biosynthesis. During a reserpine-like action (a) the monoamine tissue concentrations are decreased for weeks; (b) in brain, the acidic metabolites of 5-HT and NE are increased because the amines are released intracellularly where they are metabolized by MAO; (c) the uptake of NE appears impaired but it is normalized if the animals are injected with MAO inhibitors; (d) the uptake of the $x$-amino analogue of NE is not impaired; (e) twenty-four hours after the injection of a reserpine-like drug, the RNA concentrations in tissues containing noradrenergic cell bodies (sympathetic ganglia) are increased; this increase reflects formation of synaptic vesicles; and (f) the activity of the enzymes involved in the monoamine biosynthesis is normal. From the foregoing, it appears that the long-lasting depletion of monoamines is insufficient to characterize a reserpine-like action. In fact, the injection of $\alpha$-methyl monoamines (metaraminol, $\alpha$-methylnorepinephrine, etc.) can cause a long-lasting depletion of peripheral catecholamines ${ }^{45,46}$ similar to that elicited by reserpine. These drugs are taken up by nerve endings and stored in synaptic vesicles where they replace the transmitter ${ }^{47}$. They can be released by nerve impulses and are retrieved in nerve endings during the 


\section{E. COSTA}

resting phase. If the amine replacing the transmitter has an intrinsic activity lower than that of the natural transmitter, then, when it is released on to receptors, it causes a reduced response. For these reasons, such an amine is often termed a 'false neurochemical transmitter'. Two analogues of dopamine and 5-HT: 6-OH-dopamine and 6-OH-serotonin, respectively, concentrate in the two types of neurons. These molecules display a high chemical reactivity. When these two drugs accumulate in nerve terminals by virtue of their chemical reactivity, they cause permanent damage to the nerve endings ${ }^{48}$. Repairs to this damage can occur several months later by axonal sprouting. The depletion of tissue catecholamines caused by 6-OH-dopamine can be differentiated from that elicited by a false transmitter because the effect of 6-OH-DM is associated with a marked decrease of the enzyme's activities that are involved in the biosynthesis of NE. Some drugs are taken up by monoaminergic nerves (guanethidine is taken up by adrenergic nerves), but they cannot be readily stored in synaptic vesicles ${ }^{44}$. When guanethidine or some related compounds are injected in chronically high doses, they can cause destruction of the adrenergic nerves.

\section{Drug effects on monoamine turnover rate}

Figure 1 illustrates the present understanding of the processes involved in the release of catecholamines by nerve impulses. As shown in Figure 1, turnover rate of monoamines proceeds at a variable rate regulated by a feedback control operating at the level of the mixed function oxygenase. At rest, the amine uptake maintains the synaptic cleft free of transmitter and thus plays a role in regulating the function of nerve terminals (Figure 1). When the depolarizing wave reaches the nerve terminal, $\mathrm{Ca}^{2+}$ entry into the nerve terminal is facilitated. Simultaneously, by a phenomenon of partial

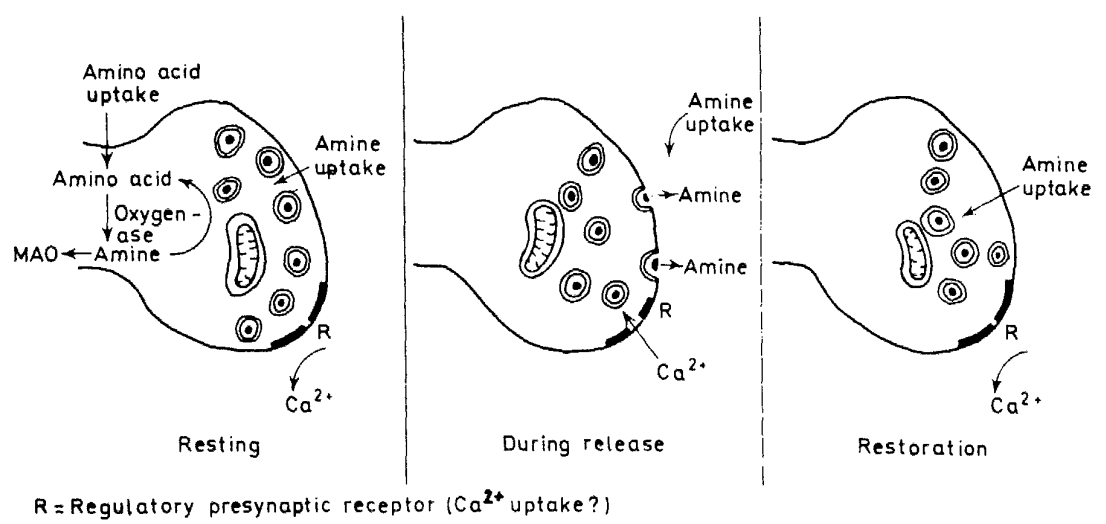

Figure 1. Speculative model of three phases of partial exocytosis. $\mathrm{R}$ is the presynaptic receptor that in this model is linked in an unknown way with the mechanism regulating $\mathrm{Ca}^{2+}$ uptake. 
exocytosis, the amine is released from the synaptic vesicle into the synaptic cleft. At the time of maximal amine release by exocytosis the amine uptake is virutally nonexistent. This is also the time in which catecholamine concentrations in the synaptic cleft reach their peak. Perhaps by acting on a presynaptic regulatory receptor ( $\mathrm{R}$ in Figure 1), the amine reduces the influx of $\mathrm{Ca}^{2+}$ and terminates the exocytosis which appears to be $\mathrm{Ca}^{2+}$-dependent. Although our understanding of the molecular mechanisms involved and their sequence is at best fragmentary, we can hypothesize that drugs may facilitate or reduce the rate of transmitter efflux from nerve terminals by interacting with the various processes outlined in Figure 1. Drugs, by acting on the $\mathrm{R}$ receptor (Figure 1), may facilitate $\mathrm{Ca}^{2+}$ influx, thus prolonging the duration of exocytosis. Conversely, they may impair $\mathrm{Ca}^{2+}$ influx and reduce the transmitter release. The receptor R depicted in Figure 1 is a regulatory site for the turnover rate of the transmitter which is susceptible to the action of drugs. These drug effects may be influenced by the nerve impulse activity. Therefore, drugs acting on the $\mathrm{R}$ receptor change the turnover rate of the transmitter to an extent which is related to nerve impulse activity. Other drugs may change the rate of transmitter turnover because they prevent the physiological retrieval of the released transmitter. With blockage of reuptake, interaction of the amine with the presynaptic $\mathrm{R}$ receptor is facilitated. As a result, the effect of these drugs tends to be independent of the rate of nerve activity. A summary of current views is presented in Table 9 .

Table 9. Drug mechanisms affecting turnover rates of neuronal monoamines

\begin{tabular}{|c|c|}
\hline Drugs increase turnover by: & Drugs decrease turnover by: \\
\hline Blocking of amine uptake & Inhibition of the rate limiting enzyme \\
\hline Blocking of postsynaptic receptors & Stimulation of postsynaptic receptors \\
\hline $\begin{array}{l}\text { Blocking of regulatory presynaptic } \\
\text { receptors }\end{array}$ & $\begin{array}{l}\text { Stimulation of regulatory presynaptic } \\
\text { receptors }\end{array}$ \\
\hline $\begin{array}{l}\text { Lowering concentrations of the } \\
\text { product functioning in feedback } \\
\text { control }\end{array}$ & $\begin{array}{l}\text { Increasing the concentrations of the } \\
\text { product functioning in feedback } \\
\text { control }\end{array}$ \\
\hline $\begin{array}{l}\text { Activating trans-synaptically the } \\
\text { rate limiting enzyme }\end{array}$ & $\begin{array}{l}\text { Increasing the rate of neuronal activity } \\
\text { by an action on neuronal loops }\end{array}$ \\
\hline $\begin{array}{l}\text { Increasing the rate of neuronal } \\
\text { activity by an action on } \\
\text { neuronal loops }\end{array}$ & \\
\hline
\end{tabular}

\section{Methods to measure monoamine turnover rate}

Table 10 lists the methods that can be used to measure isotopically the turnover rate of 5-HT in brain and peripheral tissues. While the methods in (A) and (B) have been described in previous publications, method (C) was developed only recently ${ }^{50}$. In brief:

(i) DM concentrations in noradrenergic nerves can be measured by 
E. CostA

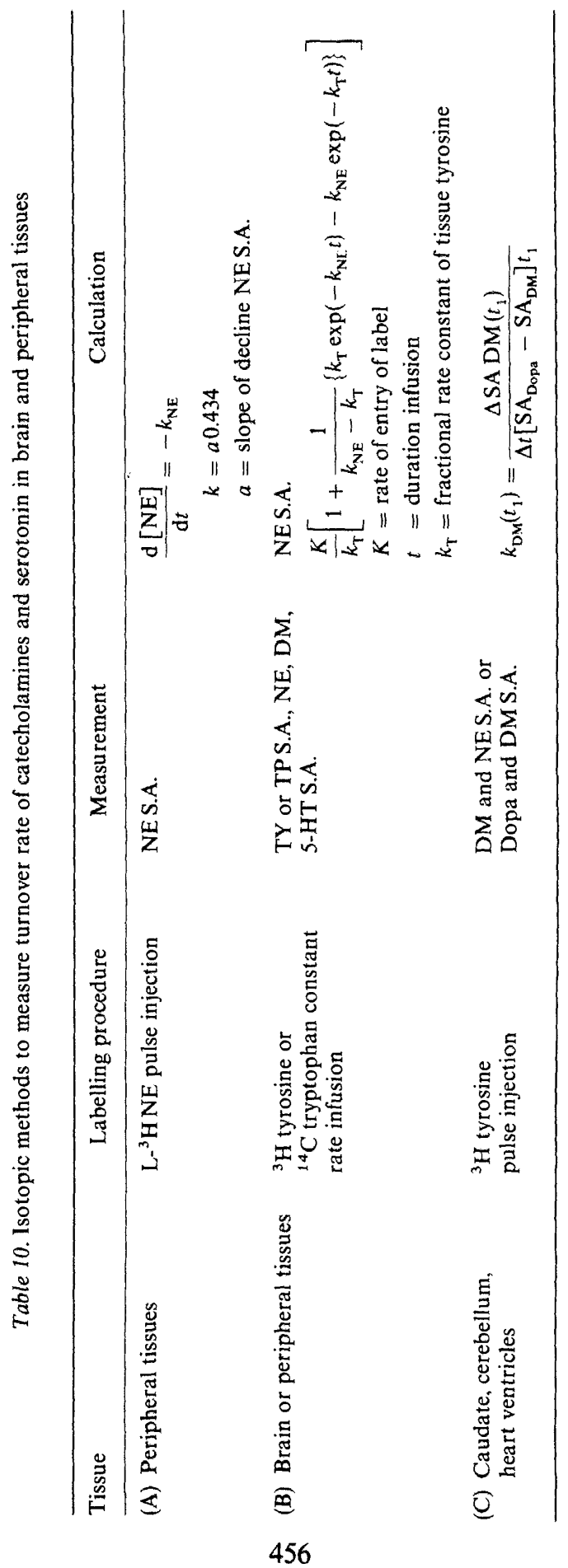


multiple ion detection using gas chromatograph-mass spectrometry. To obtain gas chromatographic separation of DM, the perfluoropropionic derivative of the amine is obtained by reacting the amine with perfluoropropionic anhydride ${ }^{51}$.

(ii) Dopa concentrations in caudate are measured fluorometrically as described in a previous publication ${ }^{52}$.

Usually, wc, as well as other authors, have measured turnover rate of 5-HT and NE from the change with time of the specific activity of the amino acid precursor at the rate-limiting step and that of the amine transmitter. Considering the model of DM biosynthesis in the caudate:

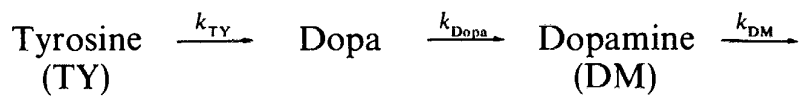

The steady state equation 1 can be proposed

$$
\frac{\mathrm{d}[\mathrm{DM}]}{\mathrm{d} t}=k_{\mathrm{Dopa}}[\mathrm{Dopa}]-k_{\mathrm{DM}}[\mathrm{DM}]=0
$$

If we have labeled the system with ${ }^{3} \mathrm{H}-\mathrm{TY}$, we can write equation 11

$$
\frac{\mathrm{d}\left[{ }^{3} \mathrm{H}-\mathrm{DM}\right]}{\mathrm{d} t}=k_{\text {Dopa }}\left[{ }^{3} \mathrm{H}-\mathrm{Dopa}\right]-k_{\mathrm{DM}}\left[{ }^{3} \mathrm{H}-\mathrm{DM}\right]
$$

by combining equation 1 and 2, we obtain equation 3

$$
\frac{\mathrm{dSA} D \mathrm{DM}}{\mathrm{d} t}=k_{\mathrm{DM}}(\mathrm{SA} \text { Dopa }-\mathrm{SA} \mathrm{DM})
$$

where

$$
\text { SA DM }=\frac{\left[{ }^{3} \mathrm{H}-\mathrm{DM}\right]}{[\mathrm{DM}]} \text { and SA Dopa }=\frac{\left[{ }^{3} \mathrm{H}-\mathrm{Dopa}\right]}{[\mathrm{Dopa}]}
$$

The question now arises whether we can substitute SA TY for SA Dopa. It is obvious that this substitution can be done if and only if SA TY = SA Dopa. This will be possible only if

$$
\frac{\mathrm{d} \text { SA Dopa }}{\mathrm{d} t}=0
$$

only in this particular case can we write (4)

$$
\frac{\mathrm{d} \mathrm{SA} \mathrm{DM}}{\mathrm{d} t}=k_{\mathrm{DM}}(\mathrm{SA} \mathrm{TY}-\mathrm{SA} \mathrm{DM})
$$

Therefore equation 4 , which is the equation frequently used to calculate turnover rate of $\mathrm{DM}^{53}$ is valid only for a short and specific time interval following the injection of ${ }^{3} \mathrm{H}-\mathrm{TY}$. In practice, this implies that in order to determine the turnover rate of a transmitter we need data to plot a time curve of the specific activity of the transmitter itself and of the immediate precursor. However, it is also necessary to assess whether this precursor pool is totally metabolized to form the transmitter. The uniformity of the metabolic fate 


\section{E. COSTA}

of this immediate precursor can be ascertained by comparing the turnover rate of this precursor to that of the transmitter.

Table 11 lists the nonisotopic methods that can be used to measure turnover rate of brain 5-HT and tissue $\mathrm{NE}^{53}$. All are based on the assumption that the various agents used to perturb the steady-state (MAO inhibitors, $\alpha$-methyltyrosine and probenecid) at the massive doses used in these experiments exert only one pharmacological action. This assumption is, however, rather unrealistic. Therefore, we must consider that these methods give, at best, only an indication of the turnover rate. In order to reduce the probability of error, it is advisable to estimate turnover rate using at least two methods in order to consolidate the indicative value of these methods.

Table 11. Nonisotopic methods to measure turnover rate of brain monoamines

\begin{tabular}{|c|c|c|c|}
\hline Amine & Perturbation & Measurement & Calculation \\
\hline $\mathrm{NE}$ & $\begin{array}{l}\text { Blockade of tyrosine } \\
\text { hydroxylase }\end{array}$ & Decline of $\mathrm{NE}$ & $\begin{array}{l}\frac{\mathrm{d}[\mathrm{NE}]}{\mathrm{d} t}=k_{\mathrm{NE}} \\
k=a 0.434 \\
a=\text { slope of NE decline }\end{array}$ \\
\hline 5-HT & Blockade of MAO & Accumulation of 5-HT & Accumulation of 5-HT \\
\hline 5-HT & Blockade of MAO & $\begin{array}{l}\text { Decline of 5-hydroxy- } \\
\text { indole acetic acid } \\
\text { (5-HIAA) }\end{array}$ & $\begin{array}{l}\frac{\mathrm{d}[5-\mathrm{HIAA}]}{\mathrm{d} t}=k 5-\mathrm{HIAA} \\
k=a 0.434 \\
a=\text { slope of 5-HIAA } \\
\quad \text { decline }\end{array}$ \\
\hline 5-HT & $\begin{array}{l}\text { Blockade of 5-HIAA } \\
\text { transport by } \\
\text { probenecid }\end{array}$ & $\begin{array}{l}\text { Accumulation of } \\
\text { 5-HIAA }\end{array}$ & Accumulation of $5-\mathrm{HIAA}$ \\
\hline
\end{tabular}

\section{Drug actions on brain monoamine turnover rate}

(i) Modifications of transmitter turnover rate unrelated to the rate of neuronal firing

Although a change in turnover rate elicited by drugs can not be readily interpreted in terms of the molecular mechanism involved, measurement of turnover rates may still be useful to localize the possible anatomical site of drug action. Moreover, when drugs do not change steady state concentrations of the transmitter, estimates of transmitter turnover rate are of value for identifying the chemical nature of the transmitter involved in a given drug action. However, when one wishes to localize a pharmacological response to a certain brain area using as a criterion the change in transmitter turnover rate, one should ascertain that this relationship is valid for a number of doses. In other words, a relationship can be proposed only if the dose 


\section{DRUG SCREENING IN NEUROPSYCHOPHARMACOLOGY}

response relationships between the two end points, pharmacological and turnover rate measurement, are similar. In Table $12 \mathrm{I}$ illustrate such a study for (+)-amphetamine, its stereo isomer, cocaine and aminorex. The data shown includes the most significant points of a dose response curve carried out with a wide dose range. It can be seen that for the drugs selected there is a remarkable correlation between the dose increasing motor activity and that accelerating the turnover rate of striatal DM. The turnover rate of telencephalic NE is not changed by the effective doses to increase motor activity. Hence, contrary to accepted opinion, Table 12 shows that (+)amphetamine and some chemically related compounds increase motor

Table 12. Effect of various drugs on motor activity and turnover rate of striatal DM and telencephalic NE

\begin{tabular}{|c|c|c|c|}
\hline Drug & Events per min $\pm S E$ & $\begin{array}{l}\text { Telencephalic NE } \\
\left(\text { nmole } \mathrm{g}^{-1} \mathrm{~h}^{-1}\right)\end{array}$ & $\underset{\left(\text { nmole } \mathrm{g}^{-1} \mathrm{~h}^{-1}\right)}{\text { Striatal DM }}$ \\
\hline Saline & $4.5 \pm 1.7$ & $2.1 \pm 0.31$ & $38 \pm 3.2$ \\
\hline $\begin{array}{c}(+) \text {-Amphetamine } \\
(1.4)\end{array}$ & $2.5 \pm 0.71$ & $1.7 \pm 0.27$ & $24 \pm 2.9$ \\
\hline $\begin{array}{c}(+) \text {-Amphetamine } \\
(2.2)\end{array}$ & $25 \pm 7.4^{*}$ & $2.3 \pm 0.41$ & $77 \pm 7.2^{*}$ \\
\hline $\begin{array}{c}(-) \text {-Amphetamine } \\
(7.4)\end{array}$ & $4.2 \pm 1.8$ & $1.9 \pm 0.36$ & $40 \pm 3.8$ \\
\hline $\begin{array}{c}\text { (-)-Amphetamine } \\
\text { (15) }\end{array}$ & $22 \pm 4.9^{*}$ & $2.7 \pm 0.41$ & $62 \pm 6.4^{*}$ \\
\hline $\begin{array}{c}\text { Cocaine } \\
(2.2)\end{array}$ & $6 \pm 2.5$ & $1.8 \pm 0.33$ & $35 \pm 6.2$ \\
\hline $\begin{array}{c}\text { Cocaine } \\
(8.8)\end{array}$ & $22 \pm 4.2^{*}$ & $1.7 \pm 0.43$ & $58 \pm 3.8^{*}$ \\
\hline $\begin{array}{l}\text { Aminorex } \\
(0.5)\end{array}$ & $7 \pm 3.2$ & $1.9 \pm 0.43$ & $41 \pm 3.5$ \\
\hline Aminorex & $77 \pm 12^{*}$ & $2.2 \pm 0.46$ & $65 \pm 3.2^{*}$ \\
\hline
\end{tabular}

$* \mathrm{P}<0.05$

Rats (5 per group) received $1 \mathrm{mc} \mathrm{kg}^{-1}$ i.v. of $3,5-{ }_{-3} \mathrm{H}$ tyrosine and 10 minutes later either saline or the drug listed in the Table; they were killed 15 minutes after the drug injection. Motor activity was measured during 15 minutes after drug injection. Steady state concentrations of NE and DM were not changed by the drugs during 15 minutes. At this time, the S.A. of tissue tyrosine was greater than that of either of the amines.

activity when given in doses that change neither the steady state concentrations nor turnover rate of telencephalic NE. The data show that doses of the drugs that increase motor activity also increase the turnover rate of striatal DM although they do not affect the steady state concentrations of this amine. This finding exemplifies the utility of turnover rate measurements to characterize the site of drug action.

(ii) Modifications of transmitter turnover rates related to the rate of neuronal firing

A characteristic property of the anticonvulsant diphenylhydantoin is that 


\section{E. COSTA}

of lowering post-tetanic potentiation (PTP) in a number of preparations. We have studied the action of diphenylhydantoin in the frog sympathetic ganglia. Since the concentration of diphenylhydantoin reducing PTP does not modify the response to single shocks, it may be inferred that diphenylhydantoin reduces the release of transmitter elicited by nerve impulses. Recent reports ${ }^{18,19}$ have indicated that the cerebellum is a site of action for diphenylhydantoin. This drug would increase the rate of firing of Purkinje cells which convey an important inhibitory input to the neurons they innervate. Stimulation of adrenergic cell bodies in locus caeruleus inhibits discharge rates of Purkinje cells ${ }^{55}$. The question then was: does diphenylhydantoin decrease this noradrenergic control because it prevents the release of transmitter from noradrenergic terminals? To answer this question, we studied the effect of diphenylhydantoin on the turnover rate of cerebellar NE in rats kept at $20^{\circ} \mathrm{C}$ and $4^{\circ} \mathrm{C}$.

Table 13. Effect of diphenylhydantoin on the fractional rate constant of cerebellar NE in rats kept at $20^{\circ} \mathrm{C}$ and $4^{\circ} \mathrm{C}$

\begin{tabular}{lccl}
\hline $\begin{array}{c}\text { Treatment } \\
\left(\mu \text { mole kg }^{-1} \text { i.p. }\right)\end{array}$ & $\begin{array}{c}\mathrm{A} \\
20^{\circ} \mathrm{C} k \mathrm{~h}^{-1}\end{array}$ & $\begin{array}{c}\mathrm{B} \\
4^{\circ} \mathrm{C} k \mathrm{~h}^{-1}\end{array}$ & $\mathrm{~B} / \mathrm{A}$ \\
\hline Saline & 0.23 & 0.54 & 2.3 \\
Diphenylhydantoin (196) & 0.28 & 0.26 & 0.92 \\
Diazepam (18) & 0.28 & 0.44 & 1.5 \\
\hline
\end{tabular}

$k$ was measured from the rate of decline of NF in cerebellum of rats receiving 2 doses of $\boldsymbol{x}$-methyltyrosine methyl ester.

The data shown in Table 13 indicate that the fractional rate constant for cerebellar NE is increased by cold exposure and that this effect is completely prevented by diphenylhydantoin. Diazepam, an anticonvulsant chemically related to diphenylhydantoin which also reduces PTP in the frog sympathetic ganglia, seems to decrease the acceleration of cerebellar NE turnover ratc elicited by cold exposure. One could speculate that by synergizing the effects of NE on the presynaptic regulatory receptor (Figure 1) both diazepam and diphenylhydantoin reduce postsynaptic potentiation and the turnover of NE in cerebellum. At this time, this is only a working hypothesis which I am presenting for your consideration as an examplc of the questions that can be asked when concepts of neurochemistry are applied to models for drug screening.

\section{REFERENCES}

${ }^{1}$ H. Ehringer and O. Hornykiewicz, Klin. Wschr. 38, 1236 (1960).

2 W. Birkmayer and O. Hornykiewicz, Wien Klin. Wschr. 73, 787 (1961).

${ }^{3}$ H. Blaschko, J. Physiol. 96, 50 (1939).

4 A. Carlsson, Pharmacol. Rev. 11, 490 (1959).

${ }^{5}$ C. A. Stone, C. A. Ross, H. C. Wenger, C. T. Ludden, J. A. Blessing, J. A. Totaro and C. C. Porter, J. Pharmacol. Exp. Ther. 136, 80 (1962). 
${ }^{6}$ S. Udenfriend and P. Zaltzman-Nirenberg, J. Pharmacol. Exp. Ther. 138, 194 (1962).

7 D. A. Walsh, E. G. Krebs, E. M. Reimann, M. A. Brostrom, J. D. Corbin, J. P. Hickenbottom,

T. R. Soderling and J. P. Perkins, Adv. Biochem. Psychopharmacol. 3, 265 (1970).

8 G. A. Robison, R. W. Butcher, and E. W. Sutherland, Ann. Rev. Biochem. 37, 149 (1968).

9 B. Weiss and E. Costa, Science 156, 1750 (1967).

10 D. A. McAtec, M. Schorderet, and P. Greengard, Science 71, 1156 (1971).

11 P. Uzunov and B. Weiss, Biochim. Biophys. Acta, in press, 1972.

12 P. Uzunov, H. M. Shein, and B. Weiss, in, Proceedings of the Fifth Congress on Pharmacology, Vol. 4, in press.

13 N. H. Neff and E. Costa, in, Proceedings of the International Symposium on Antidepressant Drugs, p. 28. Excerpta Medica Foundation, New York (1967).

14 G. C. Salmoiraghi, E. Costa, and F. E. Bloom, Ann. Rev. Pharmacol. 5, 213 (1965).

15 U. Ungerstedt, in, 6-Hydroxydopamine and Catecholamine Neurons. (Ed. T. Malmfors and H. Thoenen), p. 101. Elsevier Pub. Co., New York (1971).

16 F. Costa and A. Guidotti, in, Proceedings of Symposium: Some New Concepts in Neurotransmitter Regulation. San Diego, Calif., 1972, in press.

17 G. A. Robison, M. J. Schmidt and E. W. Sutherland, Adv. Biochem. Psychopharmacol. 3, 11 (1970).

18 R. M. Julien and L. M. Holgen, Life Sci. 10, 575 (1971).

19 R. M. Julien, Neuropharmacol. 11, 683 (19̄72).

20 B. J. Hoffer, G. R. Siggins and F. E. Bloom, Adv. Biochem. Psychopharmacol. 3, 349 (1970).

21 J. Axelrod, Science 173, 598 (1971).

22 R. Kvetnansky, G. P. Gewirtz, V. K. Weise and I. J. Kopin, Endocrinology 89, 50 (1971).

23 J. Knoll and K. Magyar, Adv. Biochem. Psychopharmacol. 5, 393 (1972).

24 R. W. Fuller, Adv. Biochem. Psychopharmacol. 5, 339 (1972).

25 E. Costa and N. H. Neff, in, Biochemistry and Pharmacology of Basal (ianglia. (Fd. E. Costa,

L. Cotc, and M. D. Yahr), p. 141, Raven Press, New York (1966).

26 T. Nagatsu, B, G. Levitt, and S. Udenfriend, J. Biol. Chem. 238, 2910 (1964).

27 E. Costa, Advan. Biochem. Psychopharmacol. 2, 169 (1970).

${ }^{28}$ J. M. Musacchio, G. L. D'Angelo and C. A. McQueen, Proc. Nat. Acad. Sci. USA 68, 2087 (1971).

29 B. Collier and F. C. Maclntosh, Can. J. Physiol. Pharmacol. 47, 127 (1969).

30 M. B. H. Youdim, G. G. S. Collins and M. Sandler, Nature 223, 626 (1969).

31 J. P. Johnston, Biochem. Pharmacol. 17, 1285 (1968).

32 C. Goridis and N. H. Neff, Brit. J. Pharmacol. 43, 814 (1971).

33 B. J. Jarrott, Neurochem. 18, 7 (1971).

34 J. Knoll and K. Magyar, Adv. Biochem. Psychopharmacol. 5, 393 (1972).

${ }^{35}$ S. H. Snyder, M. J. Kuhar, A. I. Green, J. T. Coyle and E. G. Shaskan, Int. J. Neurobiol. 13, 127 (1970).

${ }^{36}$ M. J. Kuhar and S. H. Snyder, J. Pharmacol. Exp. Ther. 171, 141 (1970),

37 L. A. Barker, M. J. Dowdall, W. B. Essman, and V. P. Wittaker, in, Drugs and Cholinergic Mechanisms in the CNS 193. Research Inst. Nat. Defense, Stockholm, Sweden (1970).

38 T. Hökfelt and A. Ljungdehl, Adv. Biochem. Psychopharmacol. 6, 1 (1972).

39 F. E. Bloom and E. Costa, Adv. Cytopharmacol. 1, 379 (1971).

40 A. D. Smith, Pharmacol. Rev. 24, 435 (1972).

41 L. B. Geffen and B. G. Livett, Physiol, Rev. 51, 98 (1971).

42 N. Weincr, G. Cloutier, R. Bjur and R. J. Pfeffer, Pharmacol. Rev. 24, 203 (1972).

43 A. Dahlström, Phil. Trans. Roy. Soc. Lond. B 261, 326 (1971).

44 J. Jarlestedt and A. Dahlström, Neuropharmacology 11, 447 (1972).

45 C. A. Stone and C. C. Porter, Pharmacol. Dev. 18, 569 (1966).

46 A. Carlsson, Pharmacol. Rev. 18, 541 (1966).

47 I. J, Kopin, J. E, Fischer, J. M. Maracchio, W. D. Horst and V. K. Weiss, J. Pharmacol. Exp. Ther. 147, 186 (1965).

48 F. E. Bloom, in, 6-Hydroxydopamine and Catecholamine Neurons. (Ed. T. Malmfors and H. Thoenen) p. 135 Elsevier Pub. Co., New York (1971).

49 C. C. Chang, E. Costa and B. B. Brodie, J. Pharmacol. 147, 303 (1965).

so E. Costa, A. R. Green, S. H. Koslow, H. F. LeFevre, A. V. Revuelta and C. Wang, Pharmacol. Rev. 24, 167 (1972).

51 F. Karoum, F. Cattabeni and E. Costa, Anal. Biochem. 47, 550 (1972).

52 E. Costa, in, Proceedings of the Fifth International Congress on Pharmacology, Vol. 4, in press. 


\section{E. COSTA}

${ }^{53}$ N. H. Neff, P. F. Spano, A. Groppetti, C. T. Wang and E. Costa, J. Pharmacol. Exp. Ther. 176, 701 (1971).

54 E. Costa and N. H. Neff, in, Handbook of Neurochemistry, Vol. 4, p. 45. Plenum Press (1970).

s5 B. J. Hoffer, G. R. Siggins, P. A. Oliver and F. E. Bloom, Ann. N. Y. Acad. Sci. 185, 531 (1971). 